\title{
Illocution Force of Rhoma Irama's Songs "Virus Corona", "Perjuangan dan Doa" and "Nilai Sehat" in Public Rise Awareness of Covid 19 Pandemic
}

\author{
Dandi Hermawan ${ }^{1 *}$, Rizky Devy Wulandari ${ }^{1}$, Mujid F Amin ${ }^{1}$, Moh. Muzakka ${ }^{1}$, and Sri Puji \\ Astuti $^{1}$ \\ ${ }^{1}$ Department of Indonesian Literature, Faculty of Humanities, Diponegoro University, Semarang- \\ Indonesia
}

\begin{abstract}
Educating due to Covid-19 spread prevention can be done using various media, for instance, through song. This research aimed to describe the illocution speech act and the function of Rhoma Irama's song lyrics as a medium to raise public awareness of Covid-19. This research conducts descriptive qualitative method and uses Searle pragmatic theory approach. The method uses in this study is scrutinize and taking notes. The result of this study found 11 assertiveness stating illocution, 4 directives asking illocution, 4 directive request illocution, 1 directive asks illocution, 1 expressive complaint illocution, and 1 saying thanks expressive illocution. Rhoma Irama's song entitled "Virus Corona" loads illocution force to raise people awareness and cognition that the world is in a serious condition due to Covid 19 pandemic. Moreover, there are also songs created before, such as "Perjuangan dan Doa" and "Nilai Sehat", which can motivate the people to keep surviving in the middle of the pandemic through healthy life and worships.
\end{abstract}

\section{Introduction}

Humans communicate through language. According to Kamus Besar Bahasa, the Indonesian language is an arbitrary system of sound symbols, which used to cooperate, interact, and self-identify by the member of society [1]. Language as a communication tool can also influence humans' behaviour [2]. Language in interlocutors' perspective, seen as listener's behaviour arranger [2]. Language is not only demand interlocutors to do something but also conduct something asked by the speaker through sentences in the form of instruction, appeal, request, or seduction. The example of implementation language as communication media can be seen in a song lyric.

A song lyric is a chain of words that also consist of rythm. Lyric has two notions which are literature work that is manifesting personal feelings and arrangement of songs [3]. Meanwhile, a song is an artwork combination of sound and language which involves the melody and voice colour of a singer [3]. Song lyric has meaning and purpose towards the listeners. Furthermore, song lyric also becomes a media to express feeling, hope, aspiration, insight, and goal. 
Rhoma Irama, one of the Indonesian singers, especially in dangdut, has released various songs aimed to express feelings and hopes. Rhoma Irama also utilizes songs to entreat people with an implicit message. Particularly in 2020, when Covid-19 has become a global plague. The pandemic makes many singers produce their songs with lyrics that can raise people awareness to keep running health protocols. Moreover, as a public figure, it is a good chance to educate people through their creations, such as songs.

As Rhoma Irama wants to build awareness of the people about Covid-19, he created a song entitled Virus Corona. The song tells the people that the world is facing a serious condition of the Coronavirus. Rhoma Irama wants to show the danger of this virus, which can make people get ill, and many places in the world should be lockdown-ed and isolated to get free from Covid-19. The song is also asked the people to keep their faith in God. Moreover, two other songs called "Perjuangan dan Doa" and "Nilai Sehat" became campaign media for those who enjoyed dangdut. The song "Perjuangan dan Doa" put a message to keep struggling even though there should be an illness in the first place. Then the song "Nilai Sehat" explains the message to keep our body healthy. The song tells the people to have a belief in getting well while sick, and it is as part of bad deeds abolishment. The messages of those three songs are still relevant with the current Covid-19 pandemic.

The passage within the song lyric can be analyzed pragmatically. Wijana states that pragmatics is one of the linguistics disciplines which studies language structure in external such as how language can be applied in communication [4]. A particular part of pragmatism that can use to uncover song lyrics is the speech act.

Searle (1969) on Speech Act: An Essay in The Philosophy of Language explained that at least there are three kinds of acts; locution, illocution, and perlocution [5]. Locution act is the act of saying something. Then, the speech function is not only for saying or giving information but also for doing something. If there is a kind of that speech, it can be called an illocution act. Illocution act is the act of doing something. Whereas a speech said by the speakers is attached to perlocutionary force or effect emerges to those who listen.

The effect that emerged can be done intentionally or accidentally by the speakers. The kind of speech act which influence interlocutors is called the perlocution act. This act describes as an act of affecting someone [5].

Searle also classifies the illocution act into five types, that is, first speech banded to speaker proposition truth such as stating, claiming, and bragging called assertive. Second, speech that aimed to make interlocutors conduct as the speaker says such as order, asking, commanding, advising, and recommending called directive. Third, speech that makes the speakers commit to doing things in the future such as sworn, declining, intimidating, assuring, and promising is called commissive. Fourth, illocution act which is an expression of feeling over someone's action such as greetings, regretting receiving, apologizing, be grateful and thanking called expressive. Fifth, the illocution act caused conciliation between reality and proposition, such as punishing, dismissing, christening, and giving name called declarative [5].

According to the explanation above, songs entitled "Virus Corona", "Perjuangan dan Doa", and "Nilai Sehat" by Rhoma Irama can be one of the media uses to raise public awareness during the Covid-19 pandemic. Those songs reveal not only the singer's personal feelings but also illocution forces listeners.

The study on the three songs of Rhoma Irama conducted with pragmatic theory's illocution speech act approach had never been done before. The study about Rhoma Irama song had been done before by Mustolehudin entitled "Moral Value in Lyrics of Dangdut Composed by Rhoma Irama", applying content analysis [6]. The second study is conducted by Muzzaka entitled "Social Criticism in the Lyric of the Song 'Indonesia' by Rhoma Irama", applying a literature sociology approach [7]. Third study by Arjaya which titled "Dangdut 
dan Rezim Orde Baru: Wacana Nasionalisasi Musik Dangdut Tahun 1990-an" applying discourse approach [8].

\section{Method}

This study conducts a descriptive qualitative method. Qualitative research tends to result from a study in descriptive form using sentences. The descriptive approach is only giving illustrations according to real conditions and situations. The object of this study is Rhoma Irama's song lyric with the limitation of only three songs. The data collection method used in this study is scrutinized and taking notes. The data collected will be analyzed using Searle's theory of speech act. The data gained that is speech consist of assertive, directive, and expressive illocution speech act.

\section{Result and Discussion}

\subsection{Assertive Illocution speech act}

An assertive speech act is a speech used to assert what the speaker believes, including fact, conclusion, and description [9]. Assertive illocution speech act found in Rhoma Irama's song lyrics are listed below:

(1) Kengerian yang mencekam, melanda segenap alam;

(2) Kala makhluk itu datang menyerang dan mematikan;

(3) Dia tak terlihat mata, tak bisa diraba;

(4) Isolasi, bersembunyi, ketakutan tak terperi;

(5) Mata dunia terbuka, betapa lemah manusia;

(6) Walaupun sudah digdaya, ternyata rapuh adanya;

(7) Hanyalah dengan mikroba bernama Corona;

(8) Sungguh telah menghancurkan sendi kehidupan;

(9) Agar dunia terbebas darinya, virus Corona;

(10) 'Pabila penyakit bersarang di badan.

(11) Rintangan sudah pasti ada;

Speech (1) until (11) include in assertive speech act which function is asserting or declare. Speech number (1) to (9) found in song lyric "Virus Corona". Speech (1) asserting that the world now is in unsafe and unstable condition due to the plague, which scared many people. That lyric tells that listeners must be cautious about the Covid-19 pandemic. Speech (2) asserting that there is a being called Covid-19 spreading across the globe to assail and kill humans. The lyric also tells Covid-19 has become a serious threat, so it is necessary to build actions to avoid it. Speech (3) asserting that Covid-19 is invisible and can not be held. The lyric tells that the virus is undetected by our five senses. Speech (4) declares that people around the world get self-isolation and hiding inside their homes because they are afraid of Covid-19. Speech (5)

states that Covid-19 comes out as an unpredictable pandemic so that the people have not prepared for any possibilities. The lyric describes that humans become weak during the pandemic. Speech (6) asserting that humans have not prepared yet for the worst risks even they had created something huge. Speech (7) asserting that humans are confronting a plague called Covid-19. Speech (8) states that Covid-19 destroys many aspects of life, such as health, education, economics, and others. Speech (9) asserting there are many ways for avoiding contact with Covid-19. Therefore, it is necessary to obey the advice and suggestion, so Covid19 ends immediately. 
Speech (10) found in song lyric "Nilai Sehat." The speech asserts a parable of the lyric that if our body got in contact with the disease, it would make everything become useless. Therefore, it shows that health is something important.

Speech (11) is part of song lyric "Perjuangan dan Doa." The speech states there will always be obstacles in life, and all we need is to face them sincerely.

\subsection{Directive Speech Act}

Directive speech act is a speech uses to ask other people to do something [9]. Directive illocution speech act found in Rhoma Irama's song lyric are listed below:

(11) Zikirkanlah nama-Nya;

(12) Sabar tawakallah;

(13) Jagalah sehatmu kawan;

(14) Hadapilah semua dengan tabah;

(15) Perjuangan harus pula disertai doa;

(16) Mohon kesembuhan;

(17) Hanyalah padaMu, Tuhan, kami mohon perlindungan;

(18) Berilah inayah untuk menghentikan;

(19) Ikhtiar dan juga doa mari kita upayakan.

Speech (11) to (14) include in directive speech act which function is requesting or asking. Directive speech on speech number (11) until (14) marked with certain particlelah in some sentences, for instance, berzikirlah, tawakallah,jagalah, and hadapilah. Speech (11) asks the people to always pray and lean on to God so they can be saved and keep healthy during Covid-19. Speech (12) asks the people to believe in God's rule. Speech (13) asks for health and prosperity during the pandemic. Speech (14) asks the people to be strong and patient, passing through the pandemic.

Speech (15) includes in directive speech act which function is commanding or advising. Speech (15) marked with the word harus, which is intended to motivate the listeners of Rhoma Irama to keep surviving in the middle of the pandemic and keep praying so we can pass the Covid 19 pandemic.

Speech (16) until (19) include in directive speech act which function is invoked. Directive speech in (16) to (19) marked with the words mohon, berilah, and upayakan. Speech (16) aimed, so the people keep praying to God for taking care of their condition during Covid-19. Speech (17) functioned for the people to lean on God for their safety. This thing relates to the effect of Covid-19, including self-isolation even death. Speech (18) aimed so that people pray to God and given solutions to end the pandemic, which caused destruction in many aspects. Speech (19) has a purpose for people keep praying so that the Covid-19 pandemic ends immediately and life back to normal.

\subsection{Expressive Speech Act}

Expressive speech act is a speech uses to express or reveal psychological act towards certain condition [10]. Expressive speech act found in Rhoma Irama's song lyric are listed below:

(21) Sakit-sakit dahulu, susah-susah dahulu

(22) Syukuri nikmatnya Tuhan;

Speech (21) include expressive speech, which function is complaining. Speech (21) marked with the phrases sakit dahulu and susah dahulu. The speech aim is to tell the life during Covid 19 that was full of agony. Covid 19 pandemic brings up many afflictions to people's life.

Speech (22) include expressive speech which function is thanking. Speech (22) marked with word syukuri. The speech aim is telling that human needs to be grateful of what has 
given in life such as health by God. So that, when it comes to Covid 19 pandemic, people who get illness can be more patient. Therefore, the speech is asking people to be grateful for the health given.

\section{Conclusion}

The song can be a suitable medium to educate people. Rhoma Irama is one of the dangdut singers in Indonesia whose thousand of admirers creating songs about Covid 19. Rhoma Irama's song entitled "Virus Corona" loads illocution force to raise people awareness and cognition that the world is in a serious condition due to Covid 19 pandemic. Moreover, there are also songs created before, such as "Perjuangan dan Doa" and "Nilai Sehat", which can motivate the people to keep surviving in the middle of the pandemic through healthy life and worships.

\section{References}

1. Language Center of National Education Department, Indonesia Dictionary (2007)

2. Chaer \& Agustina, Sosiolinguistic: Early Introduction, (2010)

3. Loebis, R. Ayuni A, Song, Youth and Democratic Culture, 2, 81-85 (2018)

4. I. D. Wijana, Pragmatic Basics, (1996)

5. Searle, Speech Acts An Essay in The Philosophy of Language, (1969)

6. Mustolehudin, Moral Value in Lyrics of Dangdut Compesed by Rhoma Irama, (2012)

7. M. Muzakka, Social Criticsm in The Lyrics of The Song "Indonesia” by Rhoma Irama, (2019)

8. D. Arjaya, Dangdut dan Rezim Orde Baru: Wacana Nasionalisasi Musik Dangdut Tahun 1990-an, (2016)

9. G. Yule, Pragmatic, (2014)

10. R. K. Rahardi, Getting acquainted with Pragmatics, (2003) 